\title{
Development of Accounting and Financial Reporting For Small and Medium-Sized Businesses in Accordance with International Financial Reporting Standards
}

\author{
Klychova G. S. ${ }^{1}$, Fakhretdinova E. N. ${ }^{2}$, Klychova A. S. ${ }^{2}$ \& Antonova N. V. ${ }^{3}$ \\ ${ }^{1}$ Kazan Federal University, Institute of Management, Economics and Finance, Kazan, 420008, Russia \\ ${ }^{2}$ Kazan State Agricultural University, Kazan, 420015, Russia \\ ${ }^{3}$ Kazan Federal University, Institute of Language, 420008, Kazan, Russia \\ Correspondence: Klychova G. S., Kazan Federal University, Institute of Management, Economics and Finance, \\ Kazan, 420008, Russia.
}

Received: March 19, 2015 Accepted: March 31, 2015 Online Published: April 30, 2015

doi:10.5539/ass.v11n11p318 URL: http://dx.doi.org/10.5539/ass.v11n11p318

\begin{abstract}
This publication considers accounting procedures and financial data reporting by small and medium size businesses in accordance with International Financial Reporting Standards (IFRS). It studies different IFRS influence zones in small and medium size businesses. The present study offers the following information: a definition for "small and medium sized business"; a model of financial accounting and reporting procedural guidelines for Russian small and medium sized businesses; approaches to creating an accounting system to prepare IFRS-based financial statements; an algorithm to transform small and medium sized businesses' accounting statements in accordance with IFRS requirements.
\end{abstract}

Keywords: small and medium sized businesses; IFRS for small and medium sized businesses, financial reporting, transformation

\section{Introduction}

At the present stage one of the key factors for successful small and medium sized business development is bringing financial reporting practices in line with international requirements. Implementation of international financial reporting standards enhances fundraising abilities, affords an opportunity to call for international tenders and to analyze financial situation among customers, makes external crediting more available (Klychova, Nizamutdinov, Safiullin, \& Mavlieva, 2014). It is a matter of utmost importance, as small businesses play a key role in developing not only the world economy but also its separate regions and sectors (Maletić \& Ceranić, 2010).

\section{Theory}

A full set of international financial reporting standards is intended for big businesses (Ildiko \& Dekan, 2013). It is complicated enough to be employed by small businesses so it was necessary to develop a simplified set of fundamental accounting principles for not big and non-publicly traded companies based on the full IFRS (Figure 1).

According to the new standard small and medium sized businesses are companies which are not publicly responsible and do not publish their financial reports for external users. Such companies do not publish debt instruments or shares on open access and do not hold third party assets.

IFRS implementation for small and medium size enterprises in Russia requires substantial legal framework upgrading. Much has already been done in this area. For instance, a new law №209-Ф3 "For small and medium entrepreneurship development in the RF" was adopted on July, 24, 2007. It specifies the criteria to classify small and medium enterprises, although a number of economists believe it necessary to revise it. We offer the following definition. Small and medium size businesses are legal entities registered in accordance with the legislation, whose core capital includes no more than $25 \%$ from the RF or its entities, municipal entities, foreign legal entities, foreign citizens, social and religious organizations (associations), charitable or any other foundations; the share of one or several legal entities who are not small and medium sized business entities does 
not exceed $25 \%$. They do not belong to state municipal unitary enterprises; they are not fudiciaries to assets of a wide community of outsiders (banks, credit unions, insurance companies, share funds, etc.); their primary activities are not associated with leasing; they do not publish their debt and equity instruments in the open market and are not issuing such instruments for open market trade (are not obliged to present financial reports to a wide range of users); the average number of employees over the preceding calendar year does not exceed 250 , and the income from sales (works, services) without value-added tax corresponds the standards set by the RF government (Klyichova \& Fahretdinova, 2014).

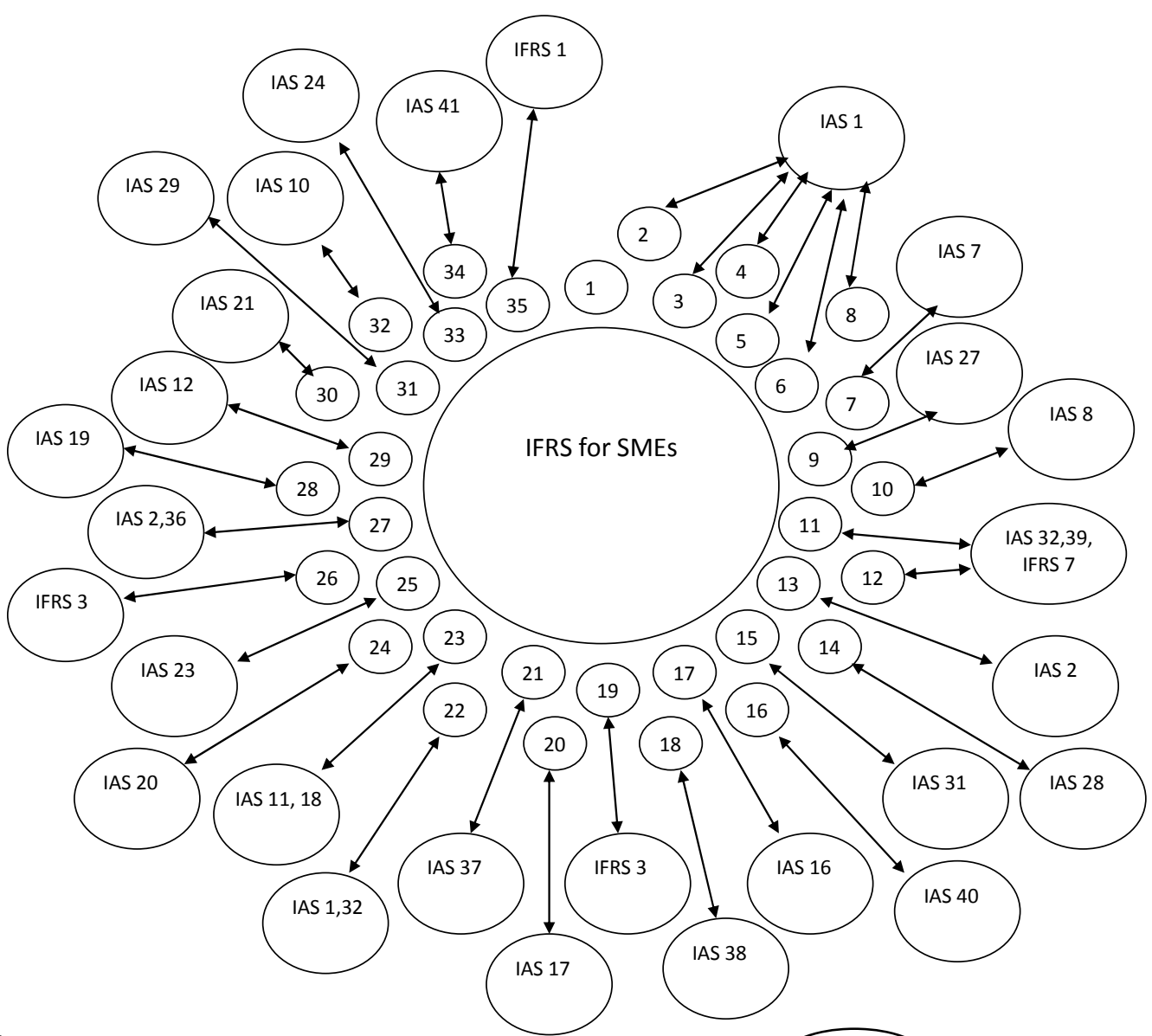

1,2... - IFRS requirements for small and medium sized enterprises; IAS 1,2. - Full IFRS requirements

Figure 1. Ratio between IFRS requirements for small and medium sized enterprises and full IFRS requirements

A number of experts find it possible to use IFRS as a basis to create a managerial accounting system (Klychova, Safiullin, \& Zakirova, 2014a, 2014b, 2014c). By harmonizing financial reporting requirements for small and medium sized enterprises with IFRS we will provide transparency to their economic activities and make the process of adapting IFRS smoother if small businesses expand to a degree and become classified as medium sized and later on large organizations (http://www.rbsys.ru).

\section{Results}

Considering the problem of harmonizing business reporting practices in accordance with international requirements special attention should be paid to conceptual framework.

In our opinion, the accounting procedures should be understood in this context as a set of measures to harmonize accounting in order to prepare financial statements based on IFRS to present it to a wide range of users.

The key element of accounting procedures is the company stuff (Popovic, 2009) and their attitude to the issue of creating an information system to introduce IFRS. 
To converge accounting standards with IRFS requirements it is necessary to conduct an analysis of the current financial reporting system in the company. The issues to be analyzed are the following: accounting, allocation of responsibilities between accountants, the current accounting standard, technical support, document management, etc.

For small and medium sized businesses centralized accounting is common practice. If small and medium sized agricultural enterprises have more than two primary production lines, the functions in financial reporting are distributed according to the accounted job.

In introducing IFRS in a business we can distinguish between several methods (schemes) of preparing financial statements:

1) If the accounting staff is large enough, it is possible to allocate individual financial reporting responsibilities among various accountants.

Under this approach the person to be responsible for preparing financial statements in accordance with IFRS is the Chief Financial Officer, who must have corresponding qualifications;

2) If the company is not large, which is usually the case with small and medium sized enterprises it is necessary to create a special IFRS department.

Under this approach it would be desirable to create the IFRS department on the basis of the finance and economy one. It is essential to provide cooperation between departments. The number of IFRS stuff will depend on the business volume. It can alternatively be divided into independent accounting areas; e.g. that of asset management or accounting for investment property, including real estate and lands (Klychova, Safiullin, \& Klychova, 2014c), or innovation processes (Klychova \& Iskhakov, 2014), etc.

The accounting procedures mechanism implies allocating responsibilities among the participants. They are normally appointed in personnel administration plan and for each staff member individually in accordance with IFRS. Interactions between participants preparing financial reports in accordance with IFRS can be approved by the IFRS department regulations, as is presented in Table 1 (a subproject).

Table 1. IFRS department regulations: subproject

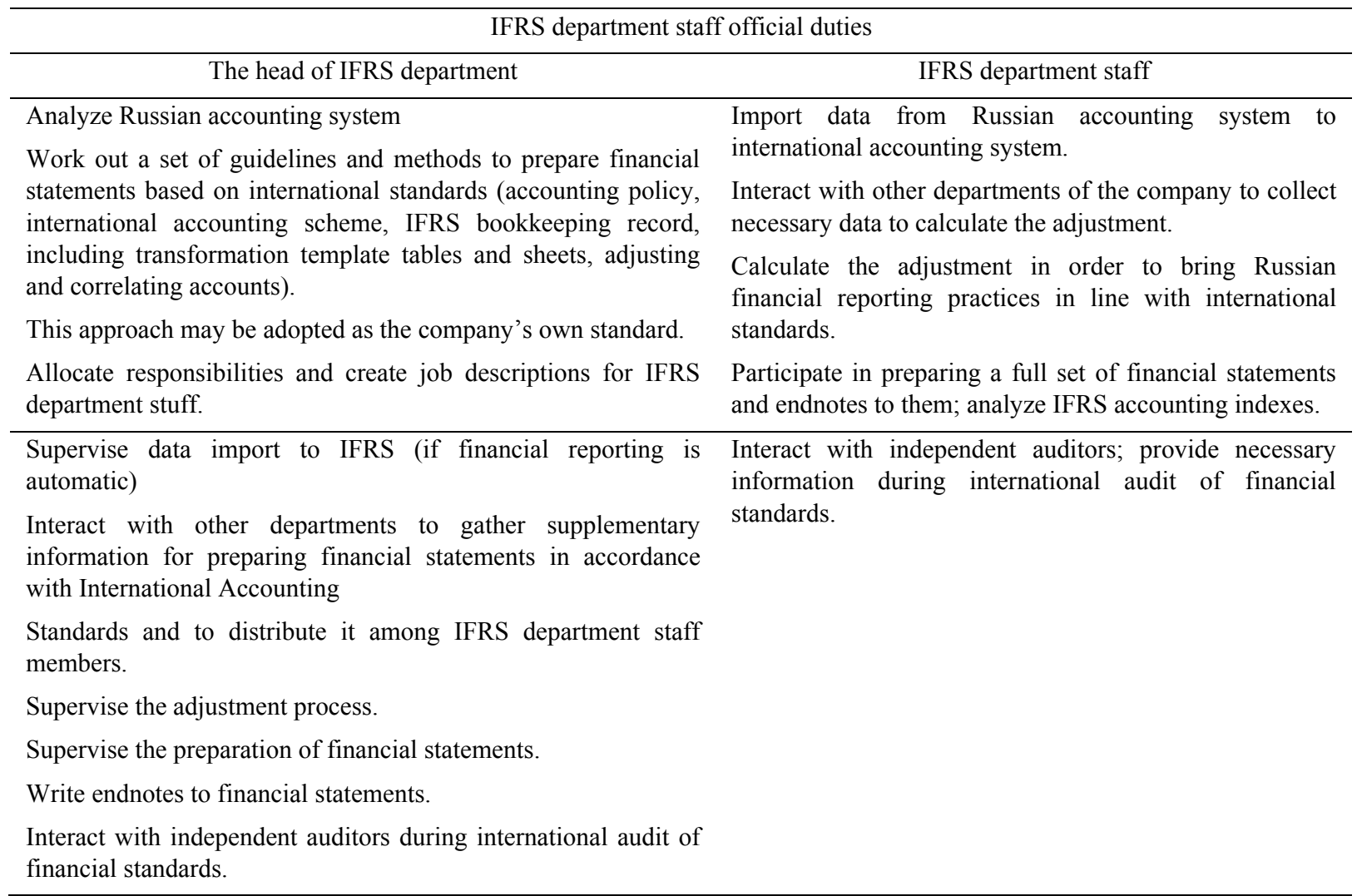


In order to raise Russian national accounting to International Accounting Standards, we consider it reasonable to treat financial reporting policy in the following manner.

Financial reporting policy is a set of guidelines, rules and policies, methods to harmonize financial reporting in accordance with IFRS requirements and reflect the transactions in bookkeeping accounts, which are adopted by the company in order to prepare and present financial statements.

Creation of a financial reporting policy must be preceded by choosing a method to adopt IFRS standards in place of national ones. Two approaches may be taken to apply IFRS for preparing financial statements. In the literature they are commonly characterized as follows:

1) Conversion is a regular process of parallel accounting and preparing financial statements in accordance with two systems (national and IFRS), which requires substantial resources (funding, labour force and time), as well as software to provide adequate and exact information;

2) Transformation is a temporary process of analyzing accounting information prepared according to Russian reporting standards and its transformation with the help of a special algorithm adopted by the company in order to meet IFRS requirements.

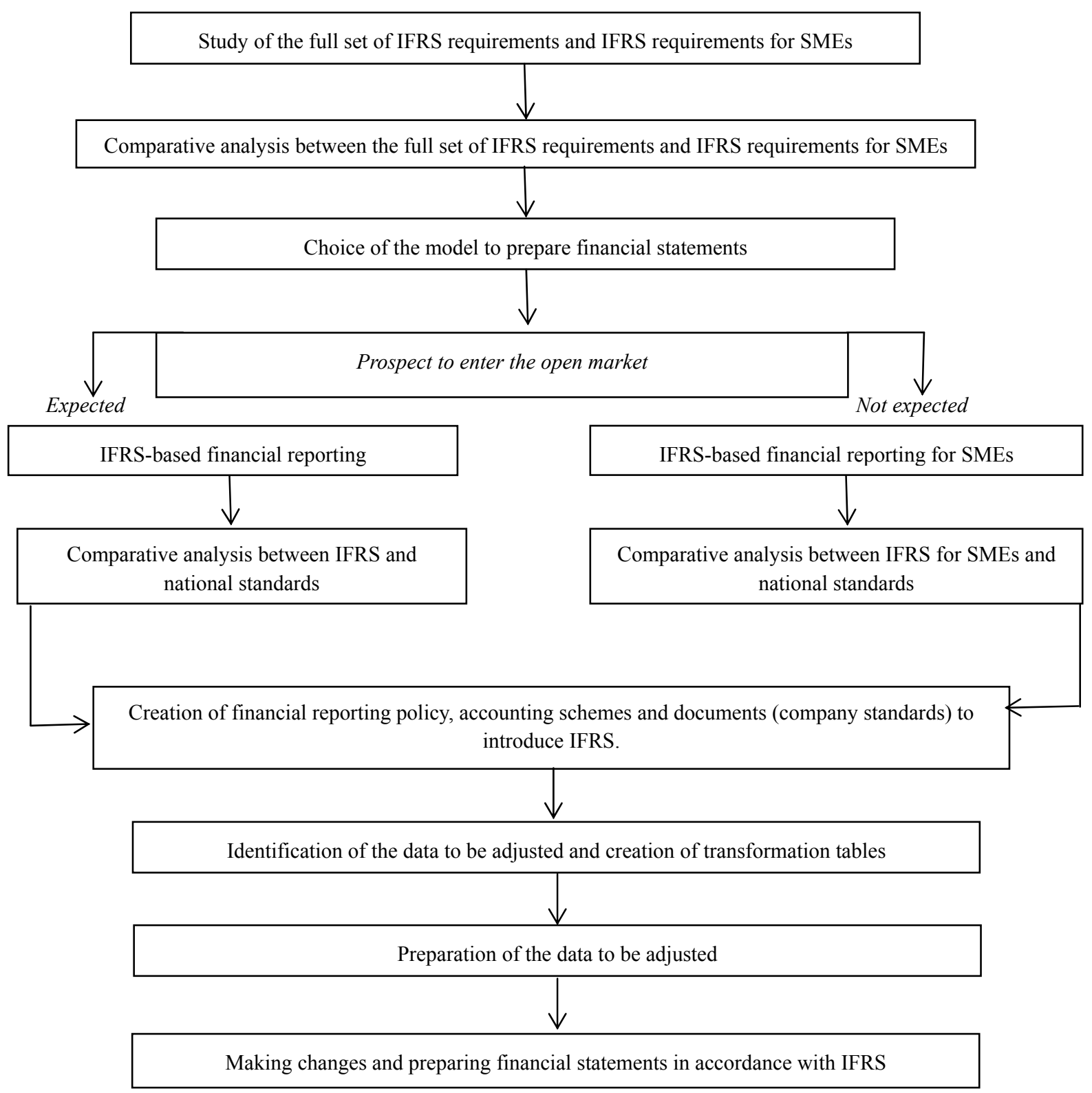

Figure 2. Algorithm to transform small and medium sized enterprises' (SMEs) financial statements to IFRS-based financial reporting 
Transformation can be either full or simplified, or go with parallel accounting. The method preferable for small sized Russian businesses is transition. The method we offer to transform financial statements for smaller sized businesses is presented in Figure 2. The method of transformation mainly depends on the IFRS model chosen for preparing statements by small and medium sized enterprises.

\section{Conclusion}

Financial statements for small and medium sized businesses based on international practices are broader as compared to Russian standards. However the reporting system allows certain simplifications for SMEs with respect to full IFRS version: a number of issues which are not applicable to a typical small business' activities are excluded (such as profit calculation per share, segment and interim reporting, reporting non-current assets held for sale or discontinued operations); the number of alternatives in accounting methods are considerably fewer. It should be mentioned that financial reporting for small and medium sized enterprises in accordance with IFRS and IAS 1 "Presentation of Financial Statements" are identical and based on the same principles.

\section{References}

Ildiko, O., \& Dekan, T. (2013). Reporting company performance - in respect of the international financial reporting standards (IFRS) (Abstract 4-5, pp. 107-113).

Klychova, G. S, Safiullin, L. N., \& Zakirova, A. R. (2014). Information-Analitical Support of Cost Management in Horse Breeding. Mediterranean Journal of Social Sciences, 5(18), 193-196.

Klychova, G. S., \& Iskhakov, A. T. (2014). The Use of Solar Batteries in Agriculture and Accounting of Generated Electricity. Mediterranean Journal of Social Sciences, 5(18), 187-191.

Klychova, G. S., Nizamutdinov, M. M., Safiullin, L. N., \& Mavlieva, L. M. (2014). Priorities of Agricultural Credit Cooperation Development. Mediterranean Journal of Social Sciences, 5(18), 215-218.

Klychova, G. S., Safiullin, L. N., \& Klychova, A. S. (2014). Features of Application of Relevant Approach in Decision Making to Participate in Tender for Assessment of Land. Mediterranean Journal of Social Sciences, 5(18), 183-186.

Klychova, G. S., Safiullin, N. Z., \& Zakirova, A. R. (2014). Organization of Cost Accounting of Fur Farming in Controlling Concept. Mediterranean Journal of Social Sciences, 5(18), 219-222.

Klyichova, G. S., \& Fahretdinova, E. N. (2014). Pravovoe obespechenie razvitiya metodologii buhgalterskogo ucheta v sub'ektah malogo i srednego predprinimatelstva agrarnogo sektora. Kazanskiy GAU, 2(32), 21-27.

Maletić, R., \& Ceranić, S. (2010). Small and medium enterprises as development factor of agribusiness in republic of Serbia (Abstract 3-4, pp. 45-51).

Moderov, S. (2011). MSFO dlya malogo i srednego biznesa. MSFO na praktike. Retrieved from http://msfo-practice.ru

Ofitsialnyiy sayt auditorsko-konsultatsionnoy gruppyi "Razvitie biznes-sistem". Retrieved from http://www.rbsys.ru

Popovic, B. (2009). Human resources management in small and medium enterprises (Abstract 1-2, pp. 71-75).

\section{Copyrights}

Copyright for this article is retained by the author(s), with first publication rights granted to the journal.

This is an open-access article distributed under the terms and conditions of the Creative Commons Attribution license (http://creativecommons.org/licenses/by/3.0/). 